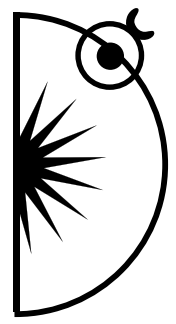

Hanna Pułaczewska

ORCID: 0000-0002-7155-8306

University of Szczecin, e-mail: hanna.pulaczewska@usz.edu.pl

\title{
Friendship Across the Border. An Overlooked Predictor of Heritage Language Skills and Cultural Knowledge in Teenagers of Polish Origin in Germany
}

\section{Przyjaźń przez granicę. Niedoceniony czynnik w kształtowaniu kompetencji językowej i wiedzy o Polsce u dzieci pochodzenia polskiego w Niemczech}

http://dx.doi.org/10.12775/PBE.2019.003

\begin{abstract}
The study demonstrates and analyzes the reasons of the outstanding impact of friendship with an age-mate in Poland on Polish language skills and knowledge about Poland in teenagers of Polish origin in Germany. In a preliminary quantitative study of 41 teenagers raised in Regensburg, Germany, data collected by means of an oral questionnaire and a standardized language test was used to estimate the association between these competences and a range of environmental and attitudinal factors. A long-term friendship with an age-mate in the home country, that had not been included in any earlier quantitative study on predictors of competence in heritage languages, was identified as a strong predictor of Polish language skills and language-dependent cultural knowledge. To find out why it played such an important role, a follow-up study has been conducted, using qualitative data collected in semi-structured interviews conducted with teenagers and their mothers. It is claimed that such friendships are
\end{abstract}


a powerful impact factor in skill development because they play a crucial role in language socialization into the heritage language community. The claim is interpreted from the perspective of language socialization approach to language acquisition, which emphasizes the identification function of language as a basic factor in its natural acquisition.

Key words: Polish, Germany, peer group, friendship, language socialization, heritage language maintenance, bilingualism.

\section{Wstęp}

Badania nad zjawiskiem naturalnego bilingwizmu, rozumianego tu jako środowiskowe przyswajanie dwóch języków w okresie dzieciństwa, są prowadzone z dużą intensywnością od lat 60. ubiegłego stulecia. Już na ich wczesnym etapie stało się jasne, że znajomość języka odziedziczonego, tzn. tego, którym posługują się rodzice lub rodzic dziecka, wśród członków mniejszości językowych jest bardzo zróżnicowana, i że zależy ona nie tylko od indywidualnych cech osoby uczącej się, lecz również w dużej mierze od warunków środowiskowych, które z jednej strony współtworzą motywację do posługiwania się danym językiem, z drugiej - decydują o rodzaju, ilości i jakości biernego i czynnego kontaktu z językiem odziedziczonym (Grosjean, 1981). Kwestią do rozstrzygnięcia pozostaje relatywna waga poszczególnych czynników środowiskowych, w ogóle i w odniesieniu do poszczególnych języków mniejszościowych w poszczególnych krajach. W licznych pracach o charakterze ilościowym poświęconych dwujęzyczności emigrantów omawia się związki jednego lub większej ilości czynników ze znajomością języka odziedziczonego. Czynnikami badanymi do tej pory w odniesieniu do różnych krajów i języków są np. poczucie tożsamości etnicznej, języki rodziców, użytkowanie języka, wsparcie społeczności i rodziny, miejsce urodzenia rodziców, zamieszkiwanie z dziadkami. Liczba czynników poddanych analizie w poszczególnych opracowaniach jest bardzo zróżnicowana i waha się od jednego (Guanglun, 2015) do trzydziestu dwóch (Shah, 2013).

W latach 2014-2016 w bawarskiej Ratyzbonie przeprowadziliśmy badania wśród nastolatków polskiego pochodzenia wychowujących się w Niemczech od urodzenia lub niemowlęctwa, mające na celu identyfikację czynników socjodemograficznych i środowiskowych wykazujących związek z ich wiedzą o Polsce i kompetencją językową w języku polskim oraz stworzenie na tej podstawie modeli predykcyjnych. Badania te miały charakter ilościowy. Niniejsze opracowanie poświęcone jest czynnikowi, który niespodziewanie wyłonił się z owych badań jako znaczący predyktor czterech spośród pięciu badanych 
rodzajów kompetencji. Czynnikiem tym jest utrzymywanie od wczesnych lat dziecięcych przyjaźni z rówieśnikiem zamieszkałym w Polsce.

Podczas gdy dane statystyczne zostały poddane wyczerpującej analizie w równoległej publikacji (będącej w przygotowaniu), niniejsza analiza ma w przeważającej mierze charakter jakościowy. Prezentujemy tu hipotezę, że przyjaźń rówieśnicza jest nie tylko predyktorem znajomości Polski i języka polskiego u młodzieży polonijnej, ale również i przede wszystkim czynnikiem znacząco wpływającym na te kompetencje. Na jej poparcie cytujemy fragmenty wywiadów przeprowadzonych z nastolatkami i ich polskojęzycznymi matkami. Za punkt wyjścia w ich interpretacji służy nam koncepcja socjalizacji językowej, w której centralną rolę odgrywa identyfikacyjna funkcja języka jako podstawa jego naturalnej akwizycji. Zanim jednak przystąpimy do prezentacji i interpretacji danych jakościowych, streszczamy pokrótce wyniki analizy ilościowej dokonanej we wspomnianym badaniu przedwstępnym, by ukazać rolę, jaka przypada pielęgnowaniu przyjaźni z rówieśnikiem w Polsce na tle innych zmiennych opisujących sytuację nastolatków, i uzasadnić w ten sposób nasze szczególne zainteresowanie badawcze tym właśnie aspektem ich życia.

\section{Metoda i próba badawcza}

Badanie zostało przeprowadzone na próbie obejmującej 41 nastolatków pochodzenia polskiego w wieku od 13 do 18 lat, zamieszkałych w bawarskiej Ratyzbonie i urodzonych w Niemczech lub przybyłych do Niemiec w wieku niemowlęcym, a w jednym przypadku w wieku trzech lat. Do zgromadzenia danych posłużyły częściowo ustrukturyzowane wywiady ustne przeprowadzone w języku wybranym przez respondentów, ankiety ustne oraz standaryzowany test kompetencji językowej. Dodatkowo przeprowadziliśmy również częściowo ustrukturyzowane wywiady z dziewiętnastoma matkami głównych respondentów, które wyjechały z Polski jako osoby dorosłe. Dziesięcioro nastolatków miało niemieckiego ojca, jeden z ojców pochodził z Austrii, dwudziestu sześciu z Polski, czworo z innego kraju.

Badanie znajomości języka polskiego obejmowało: w zakresie języka mówionego (ocenianego na skali od 0 do 6) - konwersacyjną znajomość języka polskiego, tzn. wypowiadanie się i rozumienie, w zakresie języka pisanego (ocenianego na skali od 0 do 6) umiejętność głośnego czytania, rozumienie tekstu pisanego oraz znajomość polskiej ortografii (dyktando). Dodatkowo respondenci mogli uzyskać jeden punkt za poprawną wymowę (mówienie „bez akcentu" w ocenie językoznawcy z dorobkiem naukowym w zakresie fonetyki 
i nauczycielki nauczania początkowego). Znajomość Polski jako kraju obejmowała wiedzę pozajęzykową (geograficzną, historyczną) oraz wiedzę, której posiadanie łączyło się ścisle ze znajomością języka (w dalszej części tekstu: „wiedza kulturowo-językowa”). Respondenci mieli m.in. za zadanie wymienić określoną liczbę znanych Polaków, polskich autorów, tytułów książek dla dzieci i młodzieży, filmów i seriali telewizyjnych; podać nazwę największej polskiej rzeki; podać nazwę miasta, które było stolicą Polski przed Warszawą; zaśpiewać lub zacytować hymn Polski; zdecydować, czy Polska graniczy z Czechami, Austrią i Węgrami.

Dwanaścioro nastoletnich respondentów znało język polski bardzo dobrze, tylko czworo nie znało go wcale, a dwoje rozumiało niektóre proste wypowiedzi, ale nie było w stanie wypowiadać się po polsku. Szesnaście osób w ogóle nie czytało ani nie pisało po polsku, a siedmioro posiadało umiejętność biegłego czytania oraz pisania z zastosowaniem zasad polskiej ortografii.

W przeprowadzonym wcześniej badaniu ilościowym zbadano związki między poszczególnymi rodzajami kompetencji a następującymi czynnikami:

- subiektywna ocena witalności języka polskiego w Niemczech (Bourhis et al., 1981, Allard/ Landry, 1994) - czynnik złożony, zawierający ocenę przydatności, prestiżu i liczby użytkowników polskiego w Niemczech, statusu społeczno-ekonomicznego Polaków w Niemczech, dostępności polskich mediów i kursów języka, przychylności nauczycieli wobec wychowania w dwujęzyczności, zainteresowania Niemców językiem polskim itp.,

- deklarowane zainteresowanie Polską jako krajem,

- deklarowany związek emocjonalny z Polską,

- sympatia do Polski,

- waga przywiązywana przez matkę i ojca (oddzielnie) do znajomości języka polskiego u dziecka w ocenie dziecka,

- polskie poczucie tożsamości („Czy czujesz się Polka/Polakiem?”)

- niemieckie poczucie tożsamości („Czy czujesz się Niemka/Niemcem?”),

- cechy socjodemograficzne: płeć, wiek, wykształcenie matki, wykształcenie ojca, jedynactwo, posiadanie młodszego/starszego rodzeństwa, język rodzimy ojca (polski, niemiecki, inny), okres pobytu matki w Niemczech przed urodzeniem się dziecka, typ szkoły średniej, do której uczęszcza respondent (liceum, szkoła realna, szkoła zasadnicza),

- praktyki językowe: uczęszczanie (w dowolnym okresie życia) na kurs języka polskiego (lub lekcje odbywające się w języku polskim) oraz utrzymywanie długoletniej więzi z rówieśnikiem w Polsce (co najmniej już od siódmego roku życia). 
Ponieważ zastosowanie regresji wielorakiej nie było zasadne ze względu na występowanie współzależności między zmiennymi niezależnymi, została wprowadzona metoda regresji krokowej postępującej (funkcja automatycznego modelowania liniowego w programie IBM SPSS 24) oraz analiza skupień z wykorzystaniem Bayesowskiego kryterium informacyjnego BIC (IBM SPSS 24).

Wyniki wykazały, że przyjaźń z rówieśnikiem w Polsce, a więc czynnik, który nie figuruje w ogóle we wcześniejszych studiach ilościowych na temat kompetencji językowej w języku odziedziczonym u dzieci emigrantów, wyróżnia się na tle innych. Wykazał on istotny związek ze wszystkimi aspektami kompetencji językowo-kulturowej za wyjątkiem wiedzy pozajęzykowej o Polsce i przewyższył niemal wszystkie inne czynniki co do wysokości współczynnika związku z poziomem języka mówionego, pisanego, poprawną wymową oraz wiedzą językowo-kulturową. Odegrał też kluczową rolę w określeniu skupień występujących w obrębie próby.

\section{Przyjaźń z rówieśnikiem w Polsce jako predyktor kompetencji językowej i wiedzy kulturowej}

Przyjaźń z rówieśnikiem $w$ Polsce a miejsce dziecka w strukturze rodziny i polskie poczucie tożsamości

Znamienne jest, że tylko siedmioro spośród dwudziestu siedmiorga nastolatków posiadających rodzeństwo miało przyjaciela w Polsce; w czternastoosobowej grupie jedynaków było takich osób aż dziewięć. Tylko jedna osoba mająca starsze rodzeństwo, czyli jedna osoba, która nigdy nie była jedynakiem, miała przyjaciela w Polsce. Najwidoczniej towarzystwo brata lub siostry podczas wizyt w Polsce znacznie redukuje potrzebę, a wraz z nią prawdopodobieństwo nawiązania i utrzymania stałej przyjaźni z rówieśnikiem zamieszkałym w Polsce. W szczególności dzieci, które nigdy nie doświadczyły bycia jedynakami, rzadko nawiązują takie przyjaźnie. Związki te wykazały istotność statystyczną $\mathrm{w}$ teście dwuśladowym ('posiadanie rodzeństwa' $-\chi^{2}=5,7, \mathrm{df}=1, \mathrm{p}<0,02$; 'pierwsze dziecko' $\left.-\chi^{2}=10,41, \mathrm{df}=1, \mathrm{p}<0,001\right)$.

Nastolatki, które miały przyjaciela w Polsce, czuły się w większym stopniu Polakami. Związek ten okazał się istotny statystycznie. 'Polskie poczucie tożsamości' osiągnęło średnią 2,5 na skali od 0 do 3 dla nastolatków mających przyjaciela $\mathrm{w}$ Polsce, dla pozostałych średnią 1,72 (SD1=0,516, SD2=1,051, test t-Studenta: średnie różne, $\mathrm{p}<0,005)$. 


\section{Znajomość języka mówionego i pisanego}

Wykorzystanie regresji krokowej postępującej owocowało modelami predykcyjnymi kompetencji w języku mówionym, języku pisanym oraz sumy obu kompetencji z dodatkowym uwzględnieniem poprawnej wymowy ${ }^{1}$. 'Waga' w tabeli 1 określa wartość procentową udziału danego czynnika w trafnej predykcji wartości docelowej, tzn. oceny uzyskanej w teście. Pozycję przyjaźni rówieśniczej na tle innych czynników w odniesieniu do poszczególnych rodzajów kompetencji omawiamy w kolejnych podrozdziałach.

Tabela 1. Regresja krokowa postępująca - funkcja automatycznego modelowania liniowego w programie IBM SPSS 24. Waga i istotność najlepszych predyktorów znajomości języka polskiego w języku mówionym, znajomości języka pisanego i sumy obu sprawności z dodatkowym uwzględnieniem poprawnej wymowy. Trafność predykcyjna modeli: odpowiednio 71,8\%, $78,9 \%$ i $83 \%$

\begin{tabular}{|c|c|c|c|c|c|c|c|c|}
\hline \multicolumn{3}{|c|}{ Język mówiony } & \multicolumn{3}{|c|}{ Pisanie } & \multicolumn{3}{|c|}{ Ogólna kompetencja językowa } \\
\hline Czynnik & Waga & Istotność & Czynnik & Waga & Istotność & Czynnik & Istotność & $\begin{array}{c}\text { Istotność } \\
(2-s ́ l .)\end{array}$ \\
\hline $\begin{array}{l}\text { Ważne } \\
\text { dla matki }\end{array}$ & 0,47 & 0,001 (2-śl.) & $\begin{array}{l}\text { Kurs pol- } \\
\text { skiego }\end{array}$ & 0,42 & 0,001 (2-śl.) & $\begin{array}{c}\text { Kurs } \\
\text { polskiego }\end{array}$ & 0,26 & 0,001 \\
\hline $\begin{array}{l}\text { Przyjaźń } \\
\text { w Polsce }\end{array}$ & 0,30 & 0,001 (2-śl.) & $\begin{array}{l}\text { Przyjaźń } \\
\text { w Polsce }\end{array}$ & 0,27 & 0,001 (2-śl.) & $\begin{array}{l}\text { Przyjaźń } \\
\text { w Polsce }\end{array}$ & 0,26 & 0,001 \\
\hline $\begin{array}{l}\text { Kurs } \\
\text { polskiego }\end{array}$ & 0,09 & 0,038 (2-śl.) & Typ szkoły & 0,19 & 0,001 (2-śl.) & $\begin{array}{c}\text { Polski } \\
\text { ważny dla } \\
\text { matki }\end{array}$ & 0,21 & 0,001 \\
\hline Typ szkoły & 0,08 & 0,029 (1-śl.) & $\begin{array}{c}\text { 'Czuję się } \\
\text { Niemką' } \\
\text { (korelacja } \\
\text { ujemna) }\end{array}$ & 0,07 & 0,046 (1-śl.) & Typ szkoły & 0,12 & 0,004 \\
\hline $\begin{array}{l}\text { 'Czuję się } \\
\text { Niemką' } \\
\text { (korelacja } \\
\text { ujemna) }\end{array}$ & 0,06 & 0,047 (1-śl.) & $\begin{array}{l}\text { 'Czuję się } \\
\text { Polką' }\end{array}$ & 0,05 & 0,047 (1-śl.) & $\begin{array}{l}\text { 'Czuję się } \\
\text { Polką' }\end{array}$ & 0,08 & 0,019 \\
\hline
\end{tabular}

Źródło: badania własne.

${ }^{1}$ Modele uzyskane w ten sposób dla poszczególnych kompetencji należy interpretować jako grupy czynników, których łączna znajomość pozwala najlepiej przewidzieć poziom kompetencji, a nie jako wykaz wszystkich czynników związanych z poziomem kompetencji. Niektóre zmienne niezależne nie występują w modelach, ponieważ są reprezentowane przez inne zmienne niezależne, z którymi korelują. 
Przyjaźń rówieśnicza w Polsce wykazuje wysoką korelację ze znajomością języka mówionego, uzyskując w modelu wagę 0,26 . Ponieważ korelacja może wynikać z faktu, że znajomość języka polskiego w dzieciństwie umożliwia kontakty rówieśnicze, podczas gdy brak jego znajomości już w tym okresie uniemożliwił je w praktyce, zdecydowaliśmy się powtórzyć pomiar korelacji po wyeliminowaniu z próby sześciorga dzieci, które osiągnęły bardzo niski rezultat $(0$ do 1,5$)$ w teście na znajomość języka polskiego. Pozbawienie kontaktu z polskim wynikło w czterech przypadkach z decyzji rodziców, którzy przeszli na niemiecki w okresie, gdy dziecko uczęszczało do przedszkola, a w dwóch przypadkach z nacisków samych dzieci, które w tym samym okresie zdecydowały się posługiwać się językiem niemieckim również w domu. Czynnik ,„przyjaźń rówieśnicza” o wadze 0,2 uplasował się ponownie na drugiej pozycji co do wagi jako predyktor kompetencji w mówionym języku polskim (po typie szkoły, który w tej konstelacji okazał się najważniejszy). Również w tej zmniejszonej grupie różnica średnich ocen $\mathrm{z}$ testu na znajomość mówionego języka polskiego między nastolatkami mającymi przyjaciół w Polsce od wczesnego dzieciństwa a pozostałymi wykazuje wysoką istotność statystyczną (średnie 4 i 5,6; $\mathrm{SD}=1,167, \mathrm{df}=33, \mathrm{~F}=3,496, \mathrm{p}<0,001)$. Trafność modelu wyniosła 55,5\%.

Posiadanie przyjaciela w Polsce okazało się mieć najsilniejszy związek z poprawną wymową (mówieniem „bez akcentu”) spośród wszystkich czynników, które wykazały istotny statystycznie związek z tym aspektem kompetencji językowej $\left(\chi^{2}=12,86\right.$, df $=1, p<0,001$; ponadto taki związek wykazały polskie poczucie tożsamości, uczęszczanie na kurs polskiego i wykształcenie matki). Spośród 16 respondentów w tej kategorii aż 13 nie różniło się co do wymowy od nastolatków zamieszkałych w Polsce, podczas gdy w grupie 19 nastolatków nieposiadających przyjaciół w Polsce było takich przypadków tylko sześć. Czynnik „przyjaciel w Polsce” był jedynym istotnym statystycznie korelatem braku „obcego akcentu” w analizie regresji wielokrotnej (współczynnik regresji $=1,588, \mathrm{SE}=0,727$, Beta $=1,529, \mathrm{~T}=2,185, \mathrm{p}=0,027$, test jednośladowy). Rezultat ten nie dowodzi, że inne czynniki nie grają roli, natomiast założenie, że związek pomiędzy posiadaniem przyjaciela $\mathrm{w}$ Polsce a poprawną wymową w języku polskim nie jest przypadkową cechą badanej próby, zyskuje silne wsparcie. Różnica między nastolatkami mającymi przyjaciela w Polsce a pozostałymi co do mówienia po polsku "bez obcego akcentu" była istotna statystycznie nawet po wyeliminowaniu osób niemówiących po polsku $\left(\chi^{2}=8,63\right.$, $\mathrm{df}=1, \mathrm{p}<0,005)$.

Jeśli chodzi natomiast o znajomość języka pisanego, przyjaźń z rówieśnikiem w Polsce uplasowała się już na drugiej pozycji w modelu, przy czym 
waga tego czynnika wyniosła 0,27 (Jak należało oczekiwać, najważniejszym czynnikiem okazało się uczęszczanie na kurs polskiego; czynnik ten osiągnął wagę 0,42 .)

Najlepszymi predyktorami ogólnej znajomości języka polskiego z uwzględnieniem poprawnej wymowy okazało się posiadanie przyjaciela w Polsce (waga $0,26)$ na równi z uczęszczaniem przez dowolny okres na kurs języka polskiego (waga 0,26 ).

\section{Wiedza o Polsce}

Posiadanie przyjaciela w Polsce wysunęło się na pierwsze miejsce wśród wszystkich czynników wykazujących związek z wiedzą językowo-kulturową, odpowiadając za 0,36 predykcji modelu. Nie korelowało natomiast z pozajęzykową wiedzą o Polsce (geograficzną, historyczną).

\section{Trafność predyktora „przyjaźń z rówieśnikiem w Polsce” - wyniki jednoczynnikowej analizy wariancji z kowariantami}

Dla zbadania wpływu wartości zmiennej niezależnej 'przyjaźń z rówieśnikiem w Polsce' na poziom znajomości języka i wiedzy o Polsce przy wyeliminowaniu potencjalnego wpływu innych, niezwiązanych z nią zmiennych przeprowadziliśmy jednoczynnikową analizę wariancji ANOVA z kowariantami. Analiza wykazała, że związek ze zmienną 'przyjaźń z rówieśnikiem w Polsce' zachowuje istotność statystyczną po uwzględnieniu wpływu innych zmiennych niezależnych. Jedynym rodzajem kompetencji, z którym zmienna ta nie jest związana, okazała się wiedza pozajęzykowa.

Tabela 2. Jednoczynnikowa analiza wariancji ANOVA z kowariantami

\begin{tabular}{|c|c|c|c|c|c|c|c|}
\hline \multicolumn{2}{|c|}{ Model skorygowany } & \multirow{2}{*}{$\begin{array}{l}\begin{array}{l}\text { Suma } \\
\text { kwadr. } \\
\text { typ III }\end{array} \\
10,103\end{array}$} & \multirow{2}{*}{$\begin{array}{l}\begin{array}{l}\text { Stopień } \\
\text { swobody }\end{array} \\
1\end{array}$} & \multirow{2}{*}{$\begin{array}{l}\begin{array}{l}\text { Średnia } \\
\text { kwadr. }\end{array} \\
10,103\end{array}$} & \multirow{2}{*}{$\begin{array}{l}\mathbf{F} \\
7,605\end{array}$} & \multirow{2}{*}{$\begin{array}{l}\text { Istotność } \\
\text { 2-śl. } \\
0,013\end{array}$} & \multirow{2}{*}{$\begin{array}{l}\text { Cząstkowe } \\
\eta^{2} \\
0,487\end{array}$} \\
\hline & język mówiony & & & & & & \\
\hline \multirow{4}{*}{ w Polsce } & język pisany & 21,823 & 1 & 21,823 & 21,628 & 0,001 & 0,730 \\
\hline & $\begin{array}{l}\text { sumaryczna } \\
\text { znajomość języka, } \\
\text { w tym wymowa }\end{array}$ & 82,105 & 1 & 82,105 & 17,140 & 0,002 & 0,682 \\
\hline & $\begin{array}{l}\text { wiedza } \\
\text { pozajęzykowa }\end{array}$ & 2,854 & 1 & 2,854 & 0,608 & 0,229 & 0,071 \\
\hline & $\begin{array}{l}\text { wiedza językowo- } \\
\text { kulturowa }\end{array}$ & 4,719 & 1 & 4,719 & 3,792 & 0,043 & 0,322 \\
\hline
\end{tabular}

Źródło: badania własne. 
Tabela 2 ukazuje związki zmiennej niezależnej „przyjaźń z rówieśnikiem w Polsce” ze zmiennymi zależnymi - znajomością języka polskiego i wiedzą o Polsce - po uwzględnieniu wpływu kowariantów. Uwzględniono następujące zmienne niezależne: 'czuję się Niemką', 'subiektywna witalność języka polskiego w Niemczech, 'lata poza Polską przed urodzeniem dziecka', 'interesuję się Polską', 'czuję się związana z Polską', 'lubię Polskę', 'wiek', 'płeć', 'typ szkoły', 'język ojca', 'wykształcenie ojca', 'wykształcenie matki'. Wyłączone: 'czuję się Polką', 'polski ważny dla matki', 'polski ważny dla ojca', 'pierwsze dziecko', 'ma rodzeństwo'. Zmienne, które wykazały statystycznie istotny związek z przyjaźnią rówieśniczą, nie zostały uwzględnione.

Ze względu na to, że jedynactwo i pierworodność korelowały w znacznym stopniu z posiadaniem przyjaciela w Polsce, stało się konieczne zbadanie, na ile to właśnie te czynniki same $\mathrm{w}$ sobie (a nie fakt przyjaźnienia się $\mathrm{z}$ rówieśnikiem w Polsce) mogły być przyczyną lepszej znajomości języka polskiego. Badanie wykazało, że zarówno pierworodni, jak i jedynacy co prawda lepiej znali język polski niż grupa komplementarna, ale tylko w przypadku, gdy mieli przyjaciela w Polsce.

\section{Przyjaźnie z rówieśnikami w Polsce: wywiady z nastolatkami i ich matkami}

Przyjaźnie z rówieśnikami w Polsce wykazywały statystycznie istotne związki ze stopniem znajomości języka polskiego i wiedzą językowo-kulturową nastolatków wychowanych w Ratyzbonie przez matki mówiące po polsku. Jednakże zaprezentowane dane liczbowe nie pozwalają na ocenę związku przyczynowo-skutkowego między tymi zmiennymi. Aby przekonać się, czy i na ile lepsza znajomość języka polskiego może nie tyle warunkować utrzymywanie przyjaźni z rówieśnikiem w Polsce, co być jej efektem, dokonaliśmy analizy danych jakościowych, czyli przeprowadzonych wywiadów z nastolatkami oraz ich matkami. Należy przypuszczać, że znajomość polskiego, umożliwiająca komunikowanie się bez wysiłku, pomaga w utrzymywaniu kontaktów międzyludzkich podczas wizyt w Polsce, gdyż sprawia, że są one bardziej satysfakcjonujące. Jednak więzi przyjaźni narodziły się w okresie, gdy respondenci nie chodzili jeszcze do szkoły, kiedy to wszyscy, być może z dwoma wyjątkami (dotyczącymi dzieci, których matki zdecydowały się nie przekazywać polskiego i nie wzięły udziału w wywiadach), używali polskiego na co dzień obok niemieckiego. Należy zaznaczyć, że w rodzinach, w których dokonało się przejścia na niemiecki całkowicie lub częściowo w komunikacji między dzieckiem 
a matką, zmiana ta zaczęła następować dopiero, gdy dziecko miało trzy lub cztery lata (z wyjątkiem jednej rodziny, w której częściowa zmiana nastąpiła na kilka miesięcy przed pójściem obojga dzieci do przedszkola). W efekcie w wieku przedszkolnym dzieci były do pewnego stopnia zdolne do porozumiewania się po polsku w czasie wizyt w Polsce, kiedy to były „zanurzone” w języku polskim, będącym jedynym językiem komunikacji z krewnymi i innymi członkami sieci społecznych ich rodziców. Biorąc również pod uwagę stosunkową łatwość nawiązywania kontaktów w okresie przedszkolnym na przekór barierom językowym, wnosimy, że nienawiązanie przyjaźni rówieśniczej w tym okresie w czasie pobytów w Polsce wynikało głównie z czynników pozajęzykowych, tzn. innych niż brak znajomości języka, takich jak przebywanie w towarzystwie rodzeństwa (co wynika $z$ danych liczbowych) bądź też brak rówieśników wśród krewnych i w miejscu zamieszkania w Polsce.

Dane uzyskane w wywiadach z nastolatkami i ich matkami potwierdzają znaczenie przyjaźni w akwizycji języka polskiego. W szczególności wywiady potwierdziły zmiany zachodzące w sposobie spędzania wolnego czasu, w konsumpcji treści przekazywanych przez media masowego przekazu oraz $\mathrm{w}$ odniesieniu do roli grupy rówieśniczej w tych rodzajach aktywności w okresie pokwitania (Caldas, Caron-Caldas, 2002, Okita, 2002). Nastolatki spędzały teraz mniej czasu z rodzicami, wskutek czego proporcja między komunikacją w języku polskim i niemieckim zmieniła się na korzyść niemieckiego. Autorytet rodziców zmniejszył się, ich perswazja stała się mniej skuteczna, a oni sami stali się bardziej skłonni akceptować autonomię dziecka; w efekcie nastolatki decydowały teraz bardziej samodzielnie o sposobach spędzania wolnego czasu i bardziej samodzielnie wybierały formy swojej aktywności, a to również przekładało się na wzrost udziału języka niemieckiego w ich życiu. Zwiększył się udział tych form aktywności, w których najistotniejszą rolę odgrywa grupa rówieśnicza, podczas gdy formy aktywności związane z rodziną straciły na znaczeniu. Zazwyczaj oznaczało to ograniczenie styczności z polskimi mediami, gdyż nastolatki preferowały zapoznawanie się z treściami, które mogły omawiać w swojej niemieckojęzycznej grupie rówieśniczej i przeżywać wspólnie z nią. Więcej czasu spędzały teraz w kontakcie z telewizją niemiecką, niemieckimi mediami społecznościowymi, muzyką - niekoniecznie niemiecką oraz innymi treściami dostępnymi w Internecie, będącymi przedmiotem zainteresowania grupy rówieśniczej, a konsumpcja tych treści odbywała się częściej w gronie kolegów i koleżanek. Zainteresowanie polskimi środkami masowego przekazu zmalało, ponieważ przekazywane w nich treści znajdowały się poza sferą zainteresowania kolegów i koleżanek. Postawy i mody specyficzne dla 
danej grupy wiekowej zyskały na znaczeniu w porównaniu do wpływu domu rodzinnego. Jak widzimy, w tym okresie kontakt z językiem polskim zmniejszył się, a za to wzrosła styczność z językiem niemieckim, ponieważ kontakty z rówieśnikami w Niemczech, włączając w to rodzeństwo respondentów, miały miejsce wyłącznie lub w przeważającej mierze w tym języku. Nawet jeśli niektórzy respondenci mieli w Niemczech kolegów i koleżanki, których rodzice pochodzili z Polski i którzy znali go w jakimś stopniu, komunikacja z nimi odbywała się prawie wyłącznie poprzez medium języka niemieckiego, a polski był używany sporadycznie - dla zabawy, w celu popisania się albo też w obecności rodziców, jeśli ci nastawali na używanie polskiego przez dzieci. W okresie pokwitania zachodzi duże prawdopodobieństwo, że rola polskiego w życiu dziecka wejdzie w swój 'okres krytyczny', jako że wpływ kultury młodzieżowej zagóruje nad wpływem więzi pokrewieństwa i czynników zdeterminowanych pochodzeniem etnicznym, których udział w życiu dziecka zapewnia polskojęzyczny rodzic. Wszystko to razem wzięte oznacza ograniczenie rozwoju językowego $\mathrm{w}$ języku polskim, a to z kolei prowadzi do niemożności posługiwania się nim w licznych kontekstach komunikacyjnych w sposób adekwatny do wieku nastolatka.

Na tym tle zasadnicza rola odgrywana przez przyjaciół w Polsce w podtrzymywaniu i rozwijaniu znajomości języka polskiego oraz wiedzy kulturowej o Polsce polega na tym, że stanowią oni jedyny łącznik nastolatka zamieszkałego w Niemczech z grupą rówieśniczą w Polsce i jej specyfiką kulturową, czyli subkulturą młodzieżową. Więź ta może stanowić przeciwwagę dla tendencji do relegowania polskiego na pozycję, którą jedna z dorosłych uczestniczek badania określiła jako ,język starych ludzi” - mając na myśli język odseparowany od tych potrzeb psychologicznych, które domagają się zaspokojenia poprzez kontakt $\mathrm{z}$ rówieśnikami.

Zagadnienie to ilustruje następująca wypowiedź, zaczerpnięta z wywiadu $\mathrm{z}$ nastolatkiem:

(1) R: chłopiec, 18 lat

P: Masz przyjaciół i znajomych w Polsce?

R: No mam jednego, tak.

$[\ldots]$

P: I odwiedzasz go, jak jesteś w Polsce?

R: No, odwiedzam.

P: Ile razy, jak załóżmy jesteś tydzień w Polsce, ile razy się widzicie?

R: Jak jestem tydzień, to tak trzy dni. 
P: I co robicie razem?

R: No, jaramy i oglądamy film.

P: No dobra, a jak byliście młodsi?

R: To samo, hahaha, no, oglądaliśmy albo Garfielda albo, w sumie to oglądaliśmy film, i zamawialiśmy pizzę, a jak byliśmy jeszcze młodsi, to jeszcze była faza, w której się wychodziło na dwór, to tam, gdzie jest powietrze, haha, świeże powietrze.

$[\ldots]$

P: A jak jesteś tutaj w Niemczech, to masz kontakt w jakiś sposób z Edkiem?

R: No, przez Facebooka.

P: A jak często piszesz do niego albo on do ciebie

R: No nie wiem, no zależy, jak ktoś coś znalazł śmiesznego, to się, nie wiem jak często się to zdarza, częstotliwość przypadku.

P: Ale załóżmy w roku, ile razy?

R: Częstotliwość przypadku.

P: No dziesięć razy, pięć?

R: Jaka jest - jaka jest szansa, że coś się stanie przypadkowo, hahaha, taka jest szansa, że ja napiszę Edkowi, ale zawsze mu piszę, jak jak jadę tak na tydzień przed moim wyjazdem do Polski.

P: No dobrze, a czy poznałeś przez Edka yy, albo inne dzieci w Polsce jakieś no śmieszne albo ciekawe rzeczy, do których nie miałbyś dostępu bez języka polskiego?

P: Tak.

R: A co to było?

P: Abstrachuje, to jest polscy youtuberzy, naturalni, potem Blade, Blade po polsku z lektorem to coś innego niż sam Blade, bo z lektorem to wszystko lepiej, lepiej $\mathrm{W}$ sensie jak to jest jak po dwudziestej drugiej on bierze - on tam - wulgaryzmów wolno używać w polskiej telewizji, to jest super. I hmm jeszcze na Włatcy Móch, jak byłem, nie wiem czemu mama mi w ogóle pozwalała to oglądać, wiem może gdzieś w tym jest edukacja, ale serio, Przekliniak to była trochę przesada, ale mniejsza z tym, mi się podobało.

Wywiad z matką nastolatka (50 lat) potwierdził, że zdaje sobie ona sprawę $\mathrm{z}$ istotnego wpływu kontaktu z rówieśnikiem w Polsce na rozwój znajomości języka polskiego u jej syna, co wynikało przede wszystkim z tego, iż kontakt ten stanowił motywację do konsumpcji treści medialnych w języku polskim: 
(2) R: kobieta, 50 lat

P: Co można zrobić, mieszkając w Niemczech, żeby dziecko dobrze nauczyło się polskiego?

R: Przede wszystkim to nie może być tylko język starych ludzi, bo dziadkowie okej, są interesujący do pewnego momentu, jak dziecko jeszcze potrzebuje, żeby ktoś je pobujał w hamaku na przykład.

P: No tak.

R: A potem to już się inne rzeczy liczą, u mnie na przykład dzieciaki się fascynowały w domu takim serialem amerykańskim, animowanym tylko akurat nie pamiętam, South Park, no tak, no i właśnie w Polsce też powstało coś wzorowanego na tym softparku więc oczywiście zakupiłam przy okazji, bo starałam się zawsze mieć rękę na pulsie no i faktycznie, to był strzał w dziesiątkę. Arek się nauczył trochę przekleństw, bo tam był miś Przekliniak, który przeklinał, taki właśnie urok był jego.

P: Aha haha, a jak się nazywa?

R: Co, film? Włatcy Móch przez t i o z kreską. Znasz?

P: Hahaha nie wiem.

R: Uważałam, że mu nie zaszkodzi, sama raczej bym mu nie chciała przekazywać akurat tego yy zasobu słownictwa. On się mnie nawet niedawno pytał, mama ja nie rozumiem, dlaczego ty mi to pozwoliłaś oglądać. Ano właśnie dlatego, on miał wtedy dziesięć lat i był zachwycony, tak że jak pojechał do Polski do kumpla, to już mieli o czym gadać, bo to było w Polsce bardzo na fali.

$[.$.

P: Czyli w sumie uważasz, że właśnie tak trzeba robić, tak?

R: No tak, przecież on świetnie mówił jeszcze niedawno, pisze zresztą też, bo też pisze piszą sobie na Facebooku, yyy nie, na WhatsAppie z tym kumplem, do babci no to raczej dziękuję.

Oba wywiady ukazują, że nawet przebywając w Niemczech nastolatki polskojęzyczne mogą zachować styczność z polskimi mediami, aby dotrzymać kroku rówieśnikom zamieszkałym w Polsce i wiedzieć stale, co warto znać i oglądać, na użytek wakacyjnego wyjazdu do Polski - o ile ma się tam potencjalnego towarzysza i rozmówcę, z którym będzie można dzielić się wrażeniami. Takie „dzielenie się” może również mieć miejsce w Niemczech dzięki wykorzystaniu mediów społecznościowych i technologii komunikacyjnych: 
(3) R: dziewczyna, 14 lat

R: No oglądam z przyjaciółmi y często filmy, robimy tak, że w jednej ręce mam komórkę, a na kolanach mam laptopa i mamy na przykład przed sobą jakiś film i zerujemy, żeby było na zero wszystko i potem liczymy z przyjaciółmi na telefonie, że piszę raz, piszę dwa, trzy i na trzy włączamy od razu i razem nam leci. Potem tak piszemy, komentujemy jakby, jakbyśmy razem oglądali.

P: Mhm, czyli czyli trzeba dodać jeszcze, że przyjaciele są w Polsce, tak?

R: Tak, są w Polsce wtedy, w tym czasie.

P: Są w Polsce i - i polski film?

R: Tak, tak. I to dość często to oglądamy, nie wiem, co weekend może, jeden, czasem dwa filmy.

Również znajomość języka pisanego może uzyskać pozytywny impuls w wyniku zapoznawania się z literaturą w języku polskim, niekoniecznie polską, w towarzystwie i pod kierunkiem rówieśniczki:

(4) R: dziewczyna, 13 lat

P: Aha, sama czytałaś, Kubusia Puchatka?

R: No próbowałam, albo z kuzynką wypożyczaliśmy, jak byłam w Polsce, to wypożyczaliśmy książki z biblioteki i tam, zawsze ja je czytałam i ona mi tak powiedziała, że jak coś źle, powiedziałam albo tak.

Identyfikacyjna funkcja języka jako oznaki przynależności do grupy rówieśniczej dochodzi bardzo wyraźnie do głosu w przypadkach, gdy respondenci - zarówno nastolatki, jak i ich matki - nawiązują do slangu młodzieżowego, jak w następującym przykładzie.

(5) Tłumaczenie z niemieckiego, R: chłopiec, 16 lat

P: A czy jest coś, co ci się podoba w języku polskim?

R: Slang młodzieżowy, który oni tam mają, no dla mnie jest, jakby to powiedzieć, trochę fajniejszy niż na przykład u niemieckiej młodzieży.

P: Mhm, a skąd znasz ten slang, gdzie go zasłyszałeś?

R: No słyszę go zawsze jak na przykład jak jestem w Polsce z moimi kuzynami, na przykład, jak jestem na dworze z ich ich kolegami, to przysłuchuję się właśnie jak oni mówią albo co mówią, i wtedy właśnie słyszę, jak mówią, i wtedy myślę sobie, tak, ja też tak chcę mówić, bo no fajnie, tak, mi się to podoba. 
W okresie pokwitania standardowy wariant języka polskiego przekazywany przez rodziców już nie wystarcza jako środek autoekspresji, nie spełnia bowiem funkcji wyrażania przynależności jego użytkownika do subkultury młodzieżowej. Związek między językiem a grupą wiekową jako kategorią tożsamości został wyraźnie uwidoczniony w kilku wywiadach. Następujący fragment ilustrujący rolę języka w procesie identyfikacji z grupą rówieśniczą, jak również psychologiczną potrzebę takiej identyfikacji, pochodzi z wywiadu z matką czternastolatki:

(6) R: kobieta, 43 lata

R: Ja widzę, zmierzam do tego, że jeśli te dzieciaki są w Polsce, tak jak moja Renata czy Weronika właśnie ta tutaj kuzynka, one jakby trochę odstają od polskiej młodzieży. Renata cały czas narzeka, mówi, nauczcie mnie, jak się yy rozmawia, mówi, yy jak młodzież rozmawia ze sobą po polsku, w Polsce.

(śmiech)

P: A skąd pa - a skąd pani to ma.

R: A skąd ja mam to wiedzieć, mówię Renata.

P: No właśnie, tak.

$\mathrm{R}$ : to tak się zmienia.

P: Tak.

R: Tak się zmienia, takie takie, że te te rzeczy się zmieniają, ja mówię, musisz sama i ona na przykład yy czasem się nie potrafi znaleźć, tam widzę, że nie ona jakby widzi, że od nich odstaje, oni między sobą tam rozmawiają tam jakimś tam sloganami czy czy żargonem, wszystko jedno, $\mathrm{i}-\mathrm{i}-\mathrm{i}$ jest jej trochę przykro.

Kolejny wywiad ukazuje, że kontakt z rówieśnikami w Polsce pozwala na przynajmniej częściowe opanowanie polskiego slangu. Co więcej, może on zostać wykorzystany w komunikacji w rodzinie i funkcjonować w tej sferze jako pozytywny impuls, zwiększając przyjemność z posługiwania się językiem polskim poprzez wprowadzenia do niego elementu zabawowego. Znajomość polskiego u córki respondentki poprawia się w przeciągu dwu- lub trzytygodniowego okresu spędzanego przez nią rokrocznie w Polsce, a szczególnie widoczna zmiana dotyczy właśnie zmiany w kierunku wariantu języka stosownego do jej wieku. Matka wysuwa tezę, że elementy tego socjolektu biorą swój początek z elementów kultury masowej („to są teraz jakieś angielszczyzny, to są te skróty esemesowe, którymi się pisze [...] tematy czy [...] wycieczki dotyczące [...] piosenkarzy, filmów, które lecą w polskiej telewizji [...], które modelują, moim zdaniem, ten młodzieżowy język") będących w danym momencie w mo- 
dzie wśród polskiej młodzieży. Tym samym wskazuje na wiedzę kulturową jako nieodzowny element kodu językowego, którym posługuje się młodzież:

(7) R: kobieta, 40 lat

R: A poza tym myślę, że takim chyba największym szokiem jak była mniejsza, jak jak, była w przedszkolu i spędzała sama wakacje u dziadków, bo spędziła je pierwszy raz, miesiąc czasu była, jak miała yy trzy i pół roku, bo myśmy pracowali. No to zauważyła, że yy dzieci mówią inaczej niż ona, yy dzieci od razu wyczuły na podwórku mojej mamy, bo moja mama mieszka na w blokach. Że to o z nią jest coś nie tak.

F: Aha.

R: Naturalnie, od razu, to był ona powiedziała trzy zdania i od razu było wiadomo, że to coś nie gra tutaj i myślę, że chyba nawet nie to, że miała inny akcent czy, tylko myślę, że dlatego, że się ona się po prostu wyraża tak jak my, jak dorośli, co już kompletnie nie pasowało dzieciom. Ten slang dziecięcy, podwórkowy, kompletnie ona go nie rozumiała, co oni do niej mówią, no i potem właśnie, to jest to, co pani mówiłam poprzednim razem, że ona za każdym razem jak przyjeżdża, to ona się po prostu inaczej wysławia.

F: Mhm.

R: No to jest fenomenalne. To - to - my takim językiem nie mówimy, prawda, to są teraz jakieś angielszczyzny, to są te skróty esemesowe, którymi się pisze, to jest, to są tematy czy to są na przykład takie powiedzmy wycieczki dotyczące yy piosenkarzy, filmów, które lecą w polskiej telewizji, tych rzeczy, które modelują moim zdaniem ten młodzieżowy język, czego tutaj nie ma.

F: No tak, tak, tak, a nau, a nauczyła się pani czegoś od niej?

R: No pewnie.

F: W języku polskim?

R: Oczywiście.

F: Tak?

R: No, kilku wyrazów takich właśnie.

F: Czyli przy tak, przynosi do domu po prostu i-

R: No przynosi, bo rozmawia z nami, a my po prostu pytamy, co to, bo jest to dla nas albo czasem szok, albo, no z resztą, nie będę ukrywać, że się, że się yy, że to nas dosyć sporo uczy, prawda, nie tylko pozytywnych rzeczy haha, no ale, no Boże no to też, tak, no jest -

F: To wiadomo, no wszystko wszystkie rzeczy są przydatne i potrzebne.

R: No muszę pani powiedzieć, że jest biedna trochę, jeśli o to chodzi, bo no yy 
no czasami jak właśnie Ala mówi, o to jest bardzo dobry przykład, nie kąsa bazy, znała pani takie stwierdzenie?

F: Haha, nie. (śmiech)

R: Być wylaszczonym, nie kąsać bazy, no to jest właśnie to, co ona nam przywozi, to jest bardzo fajne, bo my tego potem używamy.

Znamienne jest, że obie matki tematyzują przykrość wynikającą z braku kompetencji dziecka (do czego odnosi się zwrot „nie kąsa bazy”) w wariancie języka polskiego używanym przez jego grupę rówieśniczą.

\section{Wnioski}

Dotychczasowe badania nad znajomością języka odziedziczonego u dzieci emigrantów wskazują, że poziom znajomości języka jest wyższy u starszego rodzeństwa niż dzieci urodzonych później (Hoffmann, 1991, Döpke, 1992, Lambert,Taylor, 1996, Zentella, 1997, Shin, 2002, Shah, 2013). Wyniki przeprowadzonej przez nas analizy sugerują, że wśród dzieci polskiego pochodzenia zamieszkałych w Niemczech młodsze rodzeństwo rzadziej nawiązuje przyjaźnie z rówieśnikami zamieszkałymi w Polsce. Wynika to z mniejszej potrzeby zapewnienia sobie towarzystwa rówieśniczego podczas pobytu w Polsce, co przekłada się również na brak kontaktów z rówieśnikami zamieszkałymi w Polsce w czasie spędzanym w Niemczech. Utrzymywanie takich przyjaźni okazało się znacznie lepszym predyktorem znajomości języka, a także wiedzy językowo-kulturowej - która nie była wcześniej przedmiotem badań - niż samo tylko nieposiadanie rodzeństwa lub bycie pierwszym dzieckiem w rodzinie.

Na podstawie danych jakościowych pochodzących z wywiadów z nastolatkami i ich matkami wykazaliśmy, w jaki sposób rodzaje aktywności związane z kontaktami towarzyskimi w obrębie grupy rówieśniczej pomagają w rozwinięciu kompetencji językowej w polskim, jako języku odziedziczonym, poprzez wzmożenie konsumpcji polskojęzycznych mediów oraz umożliwienie stosownej do wieku polskojęzycznej socjalizacji kulturowo-językowej. Między innymi umożliwiło im to dostęp do kodu językowego umożliwiającego identyfikację z ich własną grupą wiekową, która odgrywa zasadniczą rolę w rozwoju osobowości nastolatka. Również wiedza językowo-kulturowa na temat Polski zwiększa się wraz z zainicjowanym przez te przyjaźnie udziałem w polskiej kulturze młodzieżowej i związaną z tym konsumpcją polskojęzycznych mediów. Jest prawdopodobne, że wyższa średnia odpowiedzi na pytanie o czu- 
cie się Polakiem/Polką wśród nastolatków posiadających przyjaciół w Polsce odzwierciedla właśnie socjalizację poprzez grupę rówieśniczą, uzupełniającą socjalizację w rodzinie przy udziale jej dorosłych członków. Ta ostatnia nie jest wystarczającą podstawą do takiej identyfikacji, ponieważ nie dostarcza młodemu człowiekowi informacji na temat adekwatnych do jego wieku ,przekonań, emocji, ról, tożsamości i wyobrażeń społecznych" (Duff, 1995, s. 508, cyt. za: Machowska-Kościak, 2013, s. 89). W literaturze na temat socjalizacji językowej definiuje się ją jako proces „doświadczany przez cale życie poprzez interakcje społeczną między 'ekspertami’ (tymi, którzy mają lepszą znajomość języka, języka pisanego, kultury itd.) a 'nowicjuszami' (posiadającymi ich niższą znajomość)" (Duff, 2012, s. 566), poprzez którą nowicjusze uzyskują dostęp do tych aspektów życia społecznego. Duff (2012, s. 564) charakteryzuje socjalizację językową jako proces, w którym jednostka dąży do uzyskania nie tyle kompetencji językowej samej w sobie, co „przynależności i zdolności do partycypacji w praktykach społeczeństwa posługującego się danym językiem". Pojęcie to, wykorzystywane przez Duff w refleksji nad akwizycją języka otoczenia przez dzieci emigrantów, w oczywisty sposób znajduje zastosowanie w odniesieniu do akwizycji języków odziedziczonych, takich jak język polski za granicą.

Zagadnienie wpływu kontaktów rówieśniczych na rozwój kompetencji językowej dziecka w języku polskim zostało poruszone w wywiadach przez cztery dorosłe respondentki. Jednakże, kiedy padło pytanie, co może zrobić rodzic, by polepszyć znajomość polskiego u dziecka wychowującego się w Niemczech, tylko dwie matki wskazały organizację kontaktów z rówieśnikami w Polsce jako jedną z form wspomagania, podczas gdy osiem wymieniło kurs języka polskiego; poza tym mówienie po polsku do dziecka pojawiło się we wszystkich odpowiedziach. Rodzic jest zatem postrzegany przede wszystkim jako dostarczyciel danych językowych oraz organizator uczestnictwa w zorganizowanych formach nauczania. Forma rodzicielskiego wsparcia dla rozwoju językowego dziecka, polegająca na zwiększaniu jego wewnętrznej motywacji do akwizycji polskiego, w formie tworzenia więzi z Polska na poziomie przynależności do grupy innej niż rodzina poprzez kontakty z polską młodzieżą, pojawia się w świadomości matek tylko marginalnie.

Z przeprowadzonych badań wypływają wnioski w formie zaleceń dla emigrantów pragnących umożliwić swoim dzieciom zachowanie więzi z krajem pochodzenia. Rola rodziców w procesie akwizycji języka odziedziczonego przez dziecko wymaga rekonceptualizacji. Ich rola jako wzorców językowych nie podlega dyskusji, natomiast badanie wykazało, że umiejętne kierowanie 
motywacją dziecka i jego dostępem do adekwatnych wzorców językowych poprzez zachęcenie go do kontaktów rówieśniczych w starej ojczyźnie oraz umożliwienie mu ich stałego podtrzymywania może mieć kluczowe znaczenie dla zachowania kompetencji językowej i kulturowej w wieku nastoletnim i później.

\section{Bibliografia}

Allard, R., Landry, R. (1994). Subjective Ethnolinguistic Vitality: A Comparison of Two Measures. International Journal of Sociology of Language, 108, s. 117-144.

Bourhis, R., Giles, H., Rosenthal, D. (1981). Notes on the Construction of a 'Subjective Vitality Questionnaire' for Ethnolinguistic Groups. Journal of Multilingual and Multicultural Development, 22, s. 145-155.

Caldas, S. J., Caron-Caldas, S. (2002). A Sociolinguistic Analysis of the Language Preferences of Adolescent Bilinguals: Shifting Allegiances and Developing Identities. Applied Linguistics, 23/4, s. 490-514. DOI: http://dx.doi.org/10.1093/applin/23.4.490.

Döpke, S. (1992). One Parent One Language: An Interactional Approach. Amsterdam: John Benjamins.

Duff, P. A. (1995). An ethnography of communication in immersion classrooms in Hungary. TESOL Quarterly, 29, s. 505-537.

Duff, P.A. (2012). Second Language Socialisation. W: A. Duranti, E. Ochs, \& B.B. Schieffelin, (red.), The Handbook of Language Socialisation (s. 564-586). London: Wiley-Blackwell.

Grosjean (1981). Life with Two Languages. An Introduction to Bilingualism. London: Harvard University Press.

Guanglun, M. (2015). A meta-analysis of the correlation between heritage language and ethnic identity. Journal of Multilingual and Multicultural Development, 36(3), s. 239-254.

Lambert, W.E., Taylor, D.M. (1996). Language in the lives of ethnic minorities: CubanAmerican families in Miami. Applied Linguistics, 17, s. 477-500. DOI: http://dx.doi. org/10.1093/applin/17.4.477.

Machowska-Kościak, M. (2013). A language socialisation perspective on knowledge and identity construction in Irish post-primary education. W: F. Farr, M. Moriarty, (red.), Language Learning and Teaching. Irish research Perspectives (s. 87-110). Bern: Peter Lang.

Okita, T. (2002). Invisible Work. Bilingualism, language choice and childrearing in intermarried families. Amsterdam: John Benjamins.

Shah, S. (2013). Factors affecting proficiency among Gujarati heritage language learners 
ORYGINALNE ARTYKUŁY BADAWCZE

on three continents. Dysertacja doktorska (niepublikowana), Washington: Washington Georgetown University.

Shin, S. (2002). Birth order and the language experience of bilingual children. TESOL Quarterly, 36(1), s. 103-113. DOI: 10.2307/3588366.

Zentella, A.C. (1997). Growing up bilingual. Malden, MA: Blackwell Publishers. 